\title{
Capital account liberalization and income inequality
}

\author{
Silke Bumann ${ }^{\mathrm{a}}$, Robert Lensink ${ }^{\mathrm{b}, *}$ \\ a Max Planck Institute for Evolutionary Biology, August-Thienemann-Straße 2, 24306 Plön, Germany \\ ${ }^{\mathrm{b}}$ Faculty of Economics and Business, University of Groningen, PO box 800, 9700 AV, Groningen, The \\ Netherlands
}

\section{A R T I C L E I N F O}

\section{Article history:}

Available online 14 November 2015

\section{Keywords:}

Capital account liberalization

Income distribution

Gini coefficient

\begin{abstract}
A B S T R A C T
This article makes both a theoretical and an empirical contribution to the literature on financial liberalization and income inequality. In the first part, we develop a tractable model that features agents with varying investment abilities and a banking sector. There are two possible interventions to liberalize the banking sector: first, a reduction in reserve requirements, and, second, an increase in the amount of foreign funds that can be used to finance domestic loans. Financial liberalization leads to enhanced banking sector efficiency and adjustments in interest rates affecting income of investors and savers, and, therefore, income inequality. Theoretically, the impact of financial liberalization on income inequality is ambiguous. Yet, the model suggests that financial liberalization will improve income distribution in countries where financial depth is high. Our empirical estimates confirm this conditional effect. More precisely, the estimates suggest that capital account liberalization only tends to lower income inequality if the level of financial depth, as measured by private credit over GDP, exceeds 25 percent.
\end{abstract}

(c) 2015 Elsevier Ltd. All rights reserved.

\section{Introduction}

Developments related to the global financial and economic crisis have raised concerns about growing income inequality within countries, and the differential effects of financial liberalization across income

\footnotetext{
This project is part of DFID/ESRC Growth Programme ES/J009067/1 “Politics, Finance and Growth”. Financial support is gratefully acknowledged.

* Corresponding author. Tel.: +31503633712.

E-mail address: b.w.lensink@rug.nl (R. Lensink).
} 
levels, leading to calls for more empirical and theoretical research on the relationship between financial liberalization and income inequality (Atkinson and Morelli, 2011).

Previous research has investigated various determinants of income inequality, such as labor markets (Gordon and Dew-Becker, 2008), technological change (Acemoglu, 2002) or institutions (Acemoglu et al., 2013). Research on the impact of financial liberalization on income distribution is scarce though. Some of the few exceptions are studies by Agnello et al. (2012), Ang, 2010, Cornia and Kiiski (2001), Delis et al. (2014) and Jaumotte et al. (2013). These studies provide mixed evidence on the impact of financial liberalization on income inequality. In a panel of 62 countries for the period 1973 to 2005, Agnello et al. (2012) find that financial reforms, measured by the aggregate financial index due to Abiad et al. (2010), is associated with less income inequality. However, their study also suggests that the effect on income distribution varies across liberalization policies. Especially directed credit and removal of excessively high reserve requirements seem important for reducing income inequality. Yet, other financial liberalization policies, such as privatization, reducing entry barriers and increases in international capital flows, do not affect income distribution. Ang (2010), focusing on India, finds that financial liberalization exacerbates income inequality. Interestingly, his study suggests that financial development reduces income inequality. Cornia and Kiiski (2001) suggest that both external and internal financial liberalization policies correlate positively with income inequality in many developing countries. In line with Agnello et al. (2012), Delis et al. (2014) find that financial liberalization, measured by the aggregate liberalization index, tightens the distribution of income for the period 1997-2005. Furthermore, they provide evidence that enhancing privatization laws, removing credit controls and lowering entry barriers reduce income inequality. However, the negative effect of financial liberalization on income inequality weakens and becomes insignificant in the case of low-income countries. Moreover, income inequality increases with security market liberalization. Jaumotte et al. (2013) find that trade globalization leads to less income inequality, whereas financial globalization induces more income dispersion.

This paper seeks to contribute to the literature by focusing on financial depth as the main channel via which capital account liberalization (a particular form of financial liberalization) affects income inequality. To the best of our knowledge, there are no other papers that pay attention to financial depth as a moderator of the impact of capital account liberalization on income distribution.

We develop a theoretical model comprising agents with varying investment abilities and a banking sector. Agents with the best investment skills become investors, and earn the highest amount of money. Agents with fewer investment skills become savers, and earn less money. The financial regulator affects banks by setting reserve requirements and by restricting the amount of foreign funds that can be used to finance domestic loans. Financial liberalization lowers the wedge between interest rates on deposits and loans and, hence, improves banking efficiency. The increase in bank efficiency and related changes in interest rates affect the incomes of investors and savers and, therefore, income inequality.

The impact of financial liberalization on income inequality is ambiguous. Yet, our model suggests that financial liberalization will improve income distribution in countries where financial depth is high. The main reason for our finding is that in countries with high financial depth, the interest rate elasticity of loan demand is high. A financial liberalization policy that improves bank efficiency and reduces borrowing costs will lead to a sharp increase in aggregate loan demand, requiring an increase in the deposit rate to restore equilibrium in the financial market. The increase in the deposit rate improves the income of savers and, hence, income distribution. However, in countries where financial depth is low, the interest elasticity of demand for loans is low, so that an increase in bank efficiency, and the related decrease in borrowing costs, will only have a minor impact on loan demand. In this case financial market equilibrium requires a decrease in the deposit rate, which reduces the income of savers and consequently increases income inequality.

We provide evidence for our theoretical predictions by conducting Generalized Method of Moments (GMM) estimations using a revised and updated cross-country dataset on income inequality by Galbraith and Kum (2005). The empirical analysis focuses on liberalizing the capital account, which is the most relevant area of intervention. Especially in economically weak countries, governments use capital controls because foreign borrowing could undermine governments' ability to control domestic funds and exchange rates (Agénor and Montiel, 2008). Over time, governments have (gradually) reduced capital controls. Although, considerable differences across countries persist (Abiad et al., 2010). 
There is a literature dealing with the impact of financial depth on income inequality (e.g., Greenwood and Jovanovic, 1990; Galor and Zeira, 1993) that is related to our paper. The distributional effects of financial depth mainly depend on whether financial depth operates on the extensive or the intensive margin (Demirgüç-Kunt and Levine, 2009). Financial depth and financial liberalization are different concepts though. In empirical studies, financial depth is usually measured by indicators such as private credit over GDP. Beck et al. (2007) conclude that an increase in financial depth reduces income inequality. Kunieda et al. (2014), on the other hand, suggest that an increase in financial depth improves income distribution only in closed economies. Financial liberalization denotes a government intervention in the financial sector. It refers to a variety of interventions, such as the removal of entry barriers for new financial institutions, privatization of financial institutions, lifted restrictions on capital accounts and the reduction of reserve requirements (Abiad et al., 2010).

The main implication of our analysis is that in countries where financial depth is low, liberalizing the capital account will probably cause an increase in income inequality. This outcome suggests that in countries with a low level of financial development, as indicated by low financial depth, a liberalization of the capital account needs to go together with additional measures to protect the initially disadvantaged groups of the population.

\section{A stylized theoretical model}

The model contains a banking sector and heterogeneous agents. In period one, agents work and/ or invest, while in period two, they consume their proceeds consisting of their income plus either the return on investments net of borrowing costs or the return on savings. Households only access the capital market via banks. Furthermore, there is no uncertainty regarding wages or interest rates. Given this simple set-up, the time dimension does not matter such that we omit time subscripts from our notation.

\subsection{The banking sector}

We consider a consolidated commercial banking sector. Banks issue loanable funds in the form of domestic deposits $(D)$ and foreign deposits $(F)$. Assets include loans to investors $(L)$ and required reserves $(R)$. A typical bank balance sheet reads as:

$$
L+R=D+F
$$

The government sets required reserves as a fixed fraction, $1-h$, of total domestic deposits:

$$
R=(1-h) D \text { with } 0<h<1
$$

The government imposes impediments to international capital mobility such that domestic agents are constrained in borrowing from abroad. Owing to inferior knowledge about domestic projects, foreign lenders do not lend directly to domestic agents. Instead, foreigners make deposits at domestic banks. Thus, all foreign capital flows take place through the domestic banking sector. In line with von Hagen and Zhang (2008), the government sets the proportion of domestic loans that can be financed by foreign funds:

$$
F=a L \text { with } 0<a<1
$$

with parameter $a$ denoting the intensity of capital controls. The interest rate on foreign deposits $\left(r_{f}\right)$ is exogenously given and always below the exogenous interest rate on domestic deposits $\left(r_{d}\right)$. As a result, domestic banks prefer to finance loans with foreign funds. However, because of capital controls, banks may only obtain a fraction of their domestic lending from abroad. An increase in parameter $a$ corresponds to capital account liberalization.

The banking sector generates zero profits. Taking into account that required reserves are not being remunerated, the zero profit condition of banks reads as: 


$$
r_{l} L=r_{d} D+r_{f} F,
$$

with $r_{l}$ being the interest rate at which banks lend money. Using equations 1 to 3 , and fixing the foreign interest rate at zero, the previous equation can be rewritten as ${ }^{1}$ :

$$
r_{l}=\frac{(1-a)}{h} r_{d}
$$

We formulate the following relationship between $r_{l}$ and $r_{d}$ :

$$
r_{d}=b r_{l} \quad \text { with } \quad b \equiv \frac{h}{1-a}, \quad 0<b<1 .
$$

Expression 6 shows that the relationship between $r_{d}$ and $r_{l}$ can be summarized in terms of the financial liberalization parameter $b$. This parameter reflects a wedge between the two interest rates: a rise in $b$, representing financial liberalization, implies a decrease in the wedge, which corresponds to an increase in bank efficiency. An increase in $b$ can be brought about by a decrease in reserve requirements and/or a decrease in capital controls (capital account liberalization).

\subsection{Private agents}

The economy is inhabited by a continuum of private agents. At the beginning of period one all agents are endowed with labor income $(w)$. Agents differ in their ability to produce investment projects. In line with Kunieda et al. (2014), agents' abilities are captured by parameter $\phi$ that is uniformly distributed over [0,1]. Each agent knows her own ability. An agent who invests $k$ will be able to sell $\phi k$ investments goods to the final production sector at price $q$. This means $q$ is the price of capital, equal to the marginal product of capital, if the production sector features perfect competition. ${ }^{2}$ For reasons of convenience, we normalize $q$ to one. Because $q$ is exogenous in our model, the normalization does not affect our results. In turn, parameter $\phi$ can be interpreted as the marginal product of investment of the private agent.

Each agent faces the following budget constraint:

$$
w+l=d+k,
$$

with $l$ and $d$ referring to individual borrowing and saving, respectively. Individual investments $k$ are always positive. Variable $w$ represents wage income.

Information asymmetries between the bank and its clients give rise to borrowing constraints such that the maximum amount of individual borrowing $l$ is linearly related to initial wealth (see also Kunieda et al., 2014):

$$
0 \leq l \leq v w \text { with } v \geq 0 .
$$

\footnotetext{
${ }^{1}$ It should be noted that the market clearing condition changes in the case of full liberalization of international capital controls, which is represented by $a=1$. If $a$ is strictly below $1(0<a<1)$, the interest rate on domestic deposits will exceed the one on foreign deposits $\left(r_{d}>r_{f}\right)$. As a result, the entire demand for deposits by domestic agents will be held in the form of domestic deposits $(D)$, and the domestic deposit rate will clear the capital market. The total demand for foreign currency denominated deposits is regulated by the government and set to $a L$. When $a=1$, the interest rate on domestic deposits $\left(r_{d}\right)$ will be determined by the exogenously given interest rate on foreign deposits $\left(r_{f}\right)$. Total demand for domestic deposits will then become 0 . The corresponding demand for deposits by domestic agents will be met by foreign-currency denominated deposits $(F)$. In this case, the capital market will be cleared by adjustments in demand for foreign denominated deposits by foreigners such that $L=F$ (note that $R=0$ and $D=0$, if there are no controls on international capital).

2 We do not model the final production sector explicitly as it plays no role for the impact of financial liberalization on income inequality in our model.
} 
We interpret parameter $v$ as financial depth. A larger $v$ means that per unit of wealth individual borrowing can be higher.

Agents maximize consumption in the second period. They face the following options. First, they can deposit their labor income $w$ at the domestic bank earning interest $r_{d}$. Second, they may invest $w$ obtaining a return equal to the individual marginal product of investment $\phi$. Third, they may borrow from banks and invest the sum of the loan and labor income, again earning a return $\phi$. The cost of borrowing equals the domestic lending rate $r_{l}$. We assume that the interest rate on deposits $r_{d}$ is always below the cost of borrowing. This means an agent will only borrow for productive reasons, or, in other words, for financing capital investments. This also implies that individual demand for domestic deposits $d$ cannot exceed initial wealth.

Formally, each agent maximizes the following function:

$$
\max _{d, l}\left(\phi k+r_{d} d-r_{l} l\right) \text {. }
$$

Expression 9 needs to be maximized subject to the two constraints in equations 8 and 7 . The solution to this problem is straightforward and yields two thresholds $T_{1} \equiv r_{l}$ and $T_{2} \equiv r_{d}$. The two thresholds are linked via the financial liberalization parameter $b$ because $r_{d}=b r_{l}$, implying $T_{2}=b T_{1}$. The thresholds characterize three types of agents, whose choices regarding saving, borrowing and investing are described below.

First, if an agent's investment ability exceeds the cost of borrowing, $\phi>T_{1}$, the agent chooses to borrow as much as possible. The loan size is set at the maximum level, the demand for domestic deposits equals zero and investment equals labor income plus total borrowing:

$$
l=v w, \quad d=0, \text { and } k=(1+v) w .
$$

Second, if an agent's investment ability is below the domestic deposit rate, $\phi<T_{2}$, she will store her labor income in the form of domestic deposits:

$$
l=0, \quad d=w, \text { and } k=0 .
$$

For these agents, the return on savings exceeds the marginal product of investment, which induces them to save.

Third, if an agent's investment ability lies between the two thresholds, $T_{2}<\phi<T_{1}$, she will invest her labor income and not demand any deposits because the return on investment is higher than the return on savings:

$$
l=0, \quad d=0, \text { and } k=w .
$$

For this group, the marginal product of investment $\phi$ is below the cost of borrowing such that these agents choose to not borrow.

Given that agents' ability is uniformly distributed over [0,1], the proportion of borrowing investors equals $1-T_{1}$, that of savers is $T_{2}$ and the proportion of agents who invest their labor income, but do not borrow, amounts to $T_{1}-T_{2}$.

\subsection{Financial market equilibrium}

Equilibrium in the financial market requires that (for details see Appendix S1):

$$
T_{1}=\frac{v}{v+b^{2}}
$$

The derivative of $T_{1}$ with respect to the financial liberalization parameter $b$ then equals: 


$$
\frac{d T_{1}}{d b}=\frac{-2 b v}{\left(b^{2}+v\right)^{2}}<0
$$

The derivative is negative which means that financial liberalization (an increase in parameter $b$ ) always leads to a decrease in the threshold and thus a decline in the borrowing cost $r_{l}$.

The derivative of threshold $\mathrm{T}_{2}$ and, thus, the deposit rate $r_{d}$ with respect to $b$ is given by:

$$
\frac{d T_{2}}{d b}=\frac{v\left(v-b^{2}\right)}{\left(b^{2}+v\right)^{2}},
$$

which can be positive or negative. But if financial depth is high with $v>b^{2}$, financial liberalization increases the interest rate on deposits. Thus, the impact of financial liberalization on $r_{d}$ depends on the level of financial depth. As we will show later, the impact of a financial liberalization on income distribution mainly depends on the impact of a financial liberalization on $r_{d}$ and hence the level of financial

depth $v$.

In order to restore the optimality of their consumption choices following a change in interest rates, agents may reallocate to the neighboring income group. For example, savers may become investors, or the other way around. This means interest rate changes translate into changes in the proportions of savers $T_{2}$, investors $T_{1}-T_{2}$, and borrowing investors $T_{1}$.

Fig. 1 illustrates the effect of financial liberalization on the equilibrium borrowing cost and deposit rate when financial depth is low. In the right panel, the downward sloping curve represents the demand for loans $\left(L=v w\left(1-r_{l}\right)\right)$, while the upward sloping curve displays the net supply of funds (demand for deposits minus reserves plus foreign funds: $N S=b^{2} r_{l} w$ ). The equilibrium borrowing cost is given at the intersection of the two curves. An increase in the level of financial liberalization $b$ raises the net supply of funds for private lending, resulting in an upward rotation of the net-supply curve. The additional funds will induce agents who invest their wealth to borrow in addition such that the financial market will clear again. The amount borrowed per investor remains the same as $v$ is constant. The left panel depicts the relationship between the two interest rates: $r_{d}=b r_{l}$. An increase in $b$ leads to a clockwise rotation of the $r_{l}$ line. Low financial depth means that the interest rate elasticity of loan demand is low. Consequently, the decline in the costs of borrowing increases aggregate loan demand less than proportionately. The equilibrium deposit rate therefore declines.

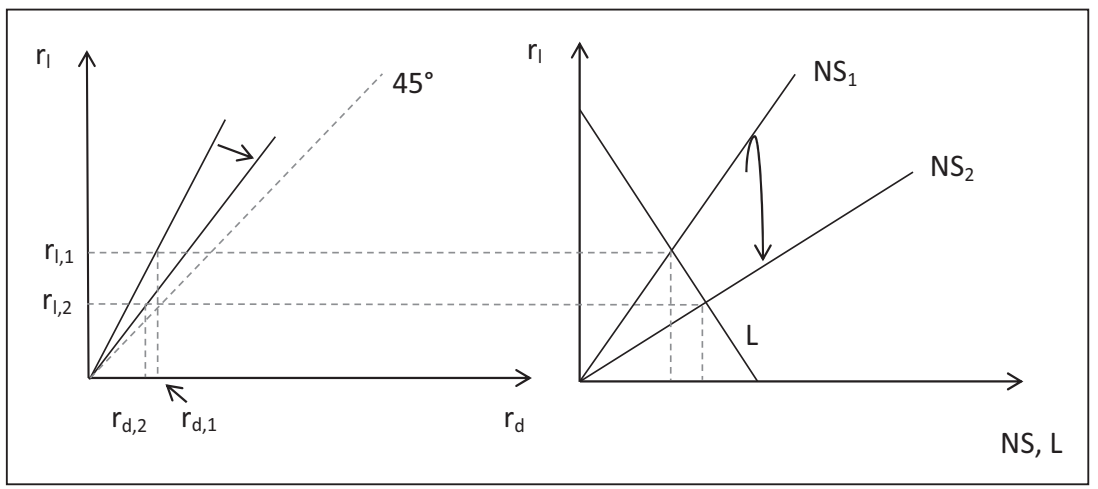

Fig. 1. Impact of financial liberalization when $v$ is low.

Notes: In the left panel $r_{l}=\frac{1}{b} r_{d}$, and in the right panel, the net supply of funds is given by $N S=b^{2} T_{1} w=b^{2} r_{l} w$. The demand for loans is $L=v\left(1-T_{1}\right) w=v\left(1-r_{l}\right) w$. An increase in $b$, brought about by a lowering of reserve requirements and/or capital account restrictions, moves both the $r_{l}$ curve and the NS curve clockwise. The equilibrium in the capital market (right panel) determines the borrowing cost. Given the borrowing cost, we can read off the interest rate on deposits (left panel). 


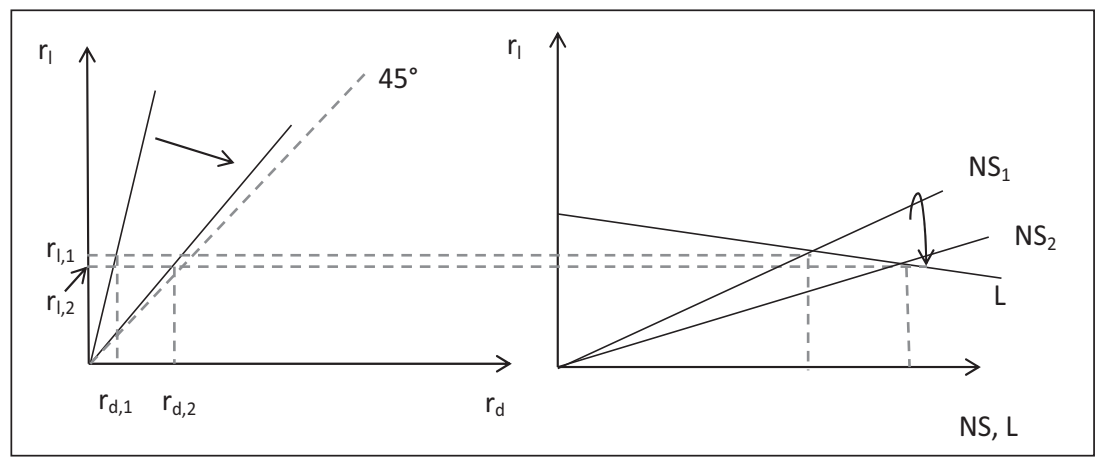

Fig. 2. Impact of financial liberalization when $v$ is high.

Notes: In the left panel, $r_{l}=\frac{1}{b} r_{d}$, and in the right panel, the net supply of funds is given by: $N S=b^{2} T_{1} w=b^{2} r_{l} w$ and the demand for loans is: $L=v w\left(1-T_{1}\right)=v w\left(1-r_{l}\right)$. An increase in $b$, brought about by a lowering of reserve requirements and/or capital account restrictions, moves both the $r_{l}$ curve and the NS curve clockwise. The equilibrium in the capital market (right panel) determines the borrowing cost. Given the borrowing cost, we can read off the interest rate on deposits (left panel).

In Fig. 2, the level of financial depth is high. As a result, the loan-demand curve is flat, implying a high interest rate elasticity. Thus, a small decrease in the lending rate will lead to a disproportionate increase in the demand for loans. An important implication is that an increase in the deposit rate may result, as shown in the left panel. Most importantly, the higher the level of financial depth, the more savers will gain from a financial liberalization. This insight turns out to be crucial for signing the impact of a financial liberalization on income distribution (see below).

\subsection{The Lorenz curve and the Gini coefficient}

We will use the Gini coefficient to examine the impact of financial liberalization on income inequality. However, before computing the Gini coefficient, we need to derive the Lorenz curve, $L C$. All calculations are given in Appendix S2.

Fig. 3 depicts a stylized Lorenz curve for our model. The $x$-axis displays the population shares of the three types of agents. The proportion of savers is $T_{2}$, the proportion of agents who invest their initial wealth but do not borrow equals $T_{1}-T_{2}$, and the one of borrowing investors amounts to $1-T_{1}$. The corresponding income shares can be read off from the $y$-axis. They are $L C\left(T_{2}\right), L C\left(T_{1}\right)-L C\left(T_{2}\right)$ and $1-L C\left(T_{1}\right)$ for savers, investors and borrowing investors, respectively. We will use the information about income and population shares below when we examine the impact of financial liberalization on the distribution of income.

The Gini coefficient can be shown to be equal to (see Appendix S2 for details):

$$
\text { Gini } \equiv 1-2 \int_{0}^{1} L C(x) d x=\frac{2 T_{1}^{3}\left(v+b^{3}\right)-3 T_{1}^{2}\left(v+b^{2}\right)+1+v}{3\left(T_{1}^{2}\left(v+b^{2}\right)-2 v T_{1}+1+v\right)} .
$$

The Gini coefficient is entirely determined by the threshold value that divides the agents into investors and workers, $T_{1}$, the financial depth parameter, $v$, as well as the financial liberalization parameter, $b$.

\subsection{Impact of financial liberalization on income inequality}

Appendix S3 provides detailed calculations of a financial liberalization on income equality. The impact of financial liberalization on income distribution is ambiguous. The reason is that financial liberalization may lead to an income rise for agents at the bottom of the distribution (the savers), but also to an increase of income for individuals at the top of the distribution due to lower borrowing costs. 


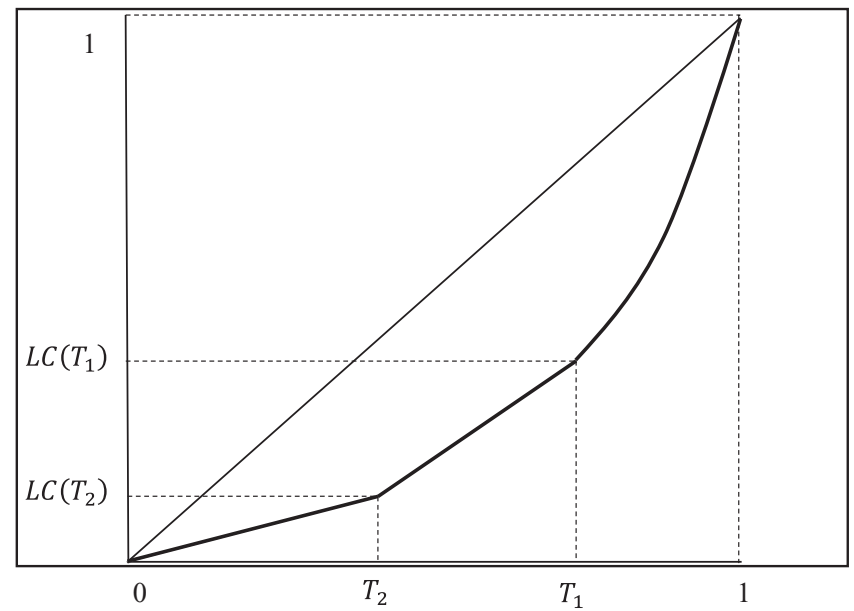

Fig. 3. Stylized Lorenz curve for the model.

Moreover, in addition to shifts in income shares, financial liberalization induces changes in population shares of the three groups, i.e. some individuals who decided not to borrow before the liberalization, become investors-borrowers due to the liberalization. When income and population shares adjust simultaneously, the overall change in inequality is hard to sign.

However, as we have shown before, the impact of financial liberalization on the lending and deposit rates depends on the level of financial depth, $v$. If financial depth is sufficiently high, the rise in the deposit rate exceeds the decline in the lending rate. This implies that the higher financial depth, the more savers will gain from the liberalization. In other words, the effect of financial liberalization on the lending rate decreases with financial depth since $d^{2} T_{1} / d b d v>0$. At the same time, the impact of financial liberalization on the deposit rate increases since $d^{2} T_{2} / d b d v<0$. As a consequence, income per saver may increase disproportionately, so may their income share. Thus, a financial liberalization is more likely to improve income distribution if financial depth is high.

\section{Empirical methodology}

Based on the theoretical analysis, we formulate the following hypothesis:

Hypothesis: A capital account liberalization improves income distribution in countries with a high level of financial depth, whereas it leads to more income inequality in countries with a low level of financial depth.

To test this hypothesis, we consider the following econometric model:

$$
\begin{aligned}
\text { inequality }_{i, t}= & \text { constant } \text { pinequality }_{i, t-1}+\lambda \text { flib }_{i, t}+\beta \text { findepth }_{i, t-1} \\
& +\delta\left(\text { flib }_{i, t} \times \text { findepth }_{i, t-1}\right)+x_{i t}^{\prime} \gamma+\eta_{i}+\mu_{t}+\varepsilon_{i, t} .
\end{aligned}
$$

In this equation, $t(t=1, \ldots, T)$ and $i(i=1, \ldots, N)$ denote time and country, respectively. The variable inequality $_{i, t}$ represents our measure of income inequality. Its lagged value inequality $y_{i, t-1}$ is included on the right-hand side to accommodate persistence in income inequality data. The variable $f l i b_{i, t}$ denotes capital account liberalization. Another important variable concerns the level of financial depth called findepth $_{i, t-1}$. The reason for using the lagged value of financial depth will become clear below. $x_{i, t}$ is a $k \times 1$ column vector of control variables. $\eta_{i}$ and $\mu_{t}$ denote a full set of country and time fixed effects, respectively. Finally, we assume that the error term $\varepsilon_{i, t}$ has zero mean conditional on the regressors $E\left[\varepsilon_{i, t} \mid \begin{array}{c}\text { inequality }_{i, t-1}, \text { flib }_{i, t}, \text { findepth }_{i, t-1}, \\ \text { flib }_{i, t} \times \text { findepth }_{i, t-1}, x_{i, t}^{\prime}, \mu_{t}, \eta_{i}\end{array}\right]=0 \forall i, t$ 
We include controls for inflation, trade openness, secondary school enrolment, the age structure of the population, population growth and real per capita GDP growth. This choice is guided by the related literature (Beck et al., 2007; Dollar and Kraay, 2002). Low income households are generally more vulnerable to increases in the price level as they have a higher portion of cash in total purchases (Albanesi, 2007). Trade openness might be a relevant factor as it could lead to changes in relative factor demands such as skilled versus unskilled labor (Anderson, 2005). Human capital is an important determinant of income inequality because of higher returns to education (Goldin and Katz, 2007). The share of the population younger than 15 or older than 65 years of age is a relevant demographic variable as inequality could be lower among retirees, but so is their average income (Perotti, 1996). Another relevant demographic variable is population growth. Countries with a smaller growth rate have a different cohort structure than countries with a fast growing population. Already, Kuznets (1955) pointed out that income inequality is affected by economic growth.

The derivative of equation 17 with respect to financial liberalization is given by:

$$
\frac{\text { dinequality }}{d f l i b}=\lambda+\delta \text { findepth }
$$

The coefficients of interest are $\lambda$ and $\delta$. The direct effect of capital account liberalization is captured by $\lambda$. The coefficient on the interaction term $\delta$ reflects whether the effect of capital account liberalization depends on financial depth. We expect a negative coefficient on the interaction term.

\subsection{Estimator}

We use a generalized method of moments (GMM) estimator to control for possible endogeneity problems. This means we take first differences of the regression equation to purge time-invariant fixed effects. We then choose suitably lagged levels of the variables as internal instruments. To improve the finite sample properties of the estimator, we augment the equation in first differences with that in levels where lagged first differences serve as instruments (Blundell and Bond, 1998). The validity of the second set of instruments rests on the assumption that changes in the instrumenting variables are uncorrelated with $\eta_{i}$. Following Blundell and Bond (1998), we report two specification tests, namely, the Hansen test, which evaluates the validity of the instruments, and a test that the error term exhibits no second-order serial correlation.

For the estimations, we will employ a five-year panel which means that we take one observation every five years. We prefer this approach over taking five-year averages because averaging would lead to a non-trivial form of serial correlation rendering consistent estimation more difficult. ${ }^{3}$

Following the advice by Roodman (2009), we add time fixed effects to control for correlation across individuals in the error term. Finally, we apply Windmeijer's (2005) correction to our standard errors to correct the finite sample bias in the two-step standard errors.

\subsection{Data}

The inconsistency and varying quality of income inequality data is a major issue because no standardized income concept exits that could serve as a foundation. Several studies have used a panel data set on Gini coefficients by Deininger and Squire (1996), which has been incorporated into the World Income Inequality Database (WIID). However, this data set has important deficiencies (Atkinson and Bourguignon, 2000; Atkinson and Brandolini, 2001; Galbraith and Kum, 2005). Galbraith and Kum (2005) try to produce more consistent and reliable income inequality data. To this end, they confine themselves to a narrower concept of income as a starting point. They propose using manufacturing pay data from the United Nations International Development Organization (UNIDO) Industrial Statistics.

\footnotetext{
${ }^{3}$ In a recent paper on redistribution and inequality, Acemoglu et al. (2013) also work with a five-year panel, instead of fiveyear averaged data.
} 
Pay data is narrower in so far as it does not include other income sources such as transfers. Yet, these data offer accuracy, consistency, and coverage across many countries, because they are based on a systematic accounting framework called the International Standard Industrial Classification (Galbraith and Kum, 2005). Moreover, the authors point out that pay and income inequality are highly correlated. In a similar vein, Krueger (1999) stresses that the demarcation between labor and non-labor income has become increasingly blurred because economic agents derive their earnings from various sources. In our estimations, we use the recently (end of 2013) updated version of the data set published by Galbraith and Kum (2005) on estimated Gini coefficients. This Gini coefficient has been calculated from pre-tax household income. ${ }^{4}$

We proxy capital account liberalization by the capital account openness index (KAOPEN) developed by Chinn and Ito (2008). A major advantage of this measure is that it seeks to capture both the strength and extensity of capital account controls. To this end, the two authors incorporate four major categories of restrictions on external accounts reported in the IMF's Annual Report on Exchange Arrangements and Exchange Restrictions (AREAER) and subject them to a principal component analysis. These four categories are restrictions on capital account transactions, the presence of multiple exchange rates, restrictions on current account transactions, and an indicator of the requirement of the surrender of export proceeds. Even though the four categories indicate the extensity of controls, Chinn and Ito (2008) argue that due to combining them, their index is also an appropriate proxy for the strength of capital controls. The basic idea is that even in countries with an open capital account, capital flows might be controlled by restricting current account transactions or by forcing companies to relinquish export proceeds. Their index measure takes such impediments into account though. The Chinn and Ito measure is a de jure measure of capital account liberalization. The literature uses also different de facto measures of capital account liberalization, such as different indicators for actual capital inflows. The latter measures may suffer from endogeneity problems, and may not reflect policyinduced liberalizations. For these reasons, we prefer the de jure measure KAOPEN. Nevertheless, as a robustness check we will also perform regressions with two de facto measures: foreign direct investment over GDP and a de facto measure of capital account openness due to Lane and Milesi-Ferretti (2007).

We measure financial depth as private credit by deposit banks and other financial institutions over gross domestic product (GDP). This data is well established and has been used before in studies that explore the impact of financial sector size on income inequality (Beck and Demirgüç-Kunt, 2008; Kunieda et al., 2014).

The data for our control variables are well developed and mostly available from standard sources, as we detail in Appendix S5.

Our final five-year panel covers 106 countries over the time period 1973 to 2008. Descriptive statistics of all variables are shown in Tables 1 and 2. Table 1 reports means, standard deviations and the total number of observations separately for developed and less developed countries. A couple of patterns are noteworthy. To begin with, developed countries exhibit on average a lower level of income inequality than less developed countries. Moreover, the first group is characterized by higher levels of capital account liberalization as well as financial depth. In addition, larger values of schooling, trade openness and GDP growth reflect the higher level of economic development of this group.

The correlation matrix in Table 2 shows that income inequality is significantly correlated with capital account liberalization and financial depth. This holds for the de jure measure (flib cap. acc.) and, to a lower extent, for the two de facto measures (flib de facto and fdi).

\footnotetext{
4 The procedure for deriving an estimated measure of income inequality based on manufacturing pay data involves three steps. First, Galbraith and Kum (2005) calculate the between-groups component of Theil's T statistic, using the different categories in the UNIDO industrial classification codes as groups. Second, they regress the Gini coefficient from the Deininger and Squire (1996) data set on their measure of manufacturing pay inequality and some additional dummy variables that capture the conceptual base of each observation (household or per capita, gross or net of taxed, income or expenditure based measure), as well as the share of manufacturing employment to total population. Third, they extract the coefficients from the described regression model. Given the estimated coefficients and data on conditioning variables, Galbraith and Kum (2005) compute the corresponding Gini coefficient of income inequality.
} 
Table 1

Descriptive statistics by level of development.

\begin{tabular}{|c|c|c|c|c|c|c|}
\hline & \multicolumn{3}{|c|}{$\begin{array}{l}\text { Upper middle \& } \\
\text { high income }\end{array}$} & \multicolumn{3}{|c|}{$\begin{array}{l}\text { Lower middle \& } \\
\text { low income }\end{array}$} \\
\hline & $\mathrm{N}$ & Mean & s.d. & $\mathrm{N}$ & Mean & s.d. \\
\hline inequality & 460 & 39.1 & 7.0 & 301 & 47.1 & 4.4 \\
\hline flib cap.acc. & 632 & 0.5 & 1.6 & 629 & -0.5 & 1.3 \\
\hline flib de facto (\%) & 611 & 320 & 1390 & 586 & 130 & 150 \\
\hline fdi $(\%)$ & 635 & 70 & 39 & 594 & 20 & 70 \\
\hline findepth (\%) & 582 & 57.2 & 41.1 & 464 & 20.5 & 17.7 \\
\hline schooling & 624 & 39.1 & 17.0 & 527 & 20.2 & 18.0 \\
\hline trade openness (\%) & 688 & 92.3 & 57.0 & 604 & 70.6 & 39.7 \\
\hline population growth (\%) & 877 & 1.4 & 1.9 & 727 & 2.2 & 1.3 \\
\hline per capita GDP growth (\%) & 720 & 1.6 & 5.8 & 627 & 1.5 & 7.0 \\
\hline inflation $(\%)$ & 734 & 25.4 & 125.1 & 628 & 83.7 & 851.6 \\
\hline age dependency ratio (\%) & 773 & 59.5 & 15.7 & 712 & 84.3 & 15.3 \\
\hline
\end{tabular}

Notes: The level of development is based on the classification of the World Bank. The underlying data is a five-year panel where one observation every five years from 1973 to 2008 has been used. The variable definitions can be found in Table S5.2 (Variable Sources and Definitions) of the appendix.

Table 2

Correlation matrix.

\begin{tabular}{|c|c|c|c|c|c|c|c|c|c|c|c|c|}
\hline & & (1) & (2) & (3) & (4) & (5) & (6) & (7) & (8) & (9) & (10) & (11) \\
\hline (1) & inequality & 1.00 & & & & & & & & & & \\
\hline (2) & flib cap.acc. & $\begin{array}{l}-0.26 \\
(0.00)\end{array}$ & 1.00 & & & & & & & & & \\
\hline (3) & flib de facto & $\begin{array}{l}-0.09 \\
(0.02)\end{array}$ & $\begin{array}{c}0.32 \\
(0.00)\end{array}$ & 1.00 & & & & & & & & \\
\hline (4) & fdi & $\begin{array}{l}-0.09 \\
(0.02)\end{array}$ & $\begin{array}{c}0.23 \\
(0.00)\end{array}$ & $\begin{array}{c}0.98 \\
(0.00)\end{array}$ & 1.00 & & & & & & & \\
\hline (5) & private credit & $\begin{array}{l}-0.47 \\
(0.00)\end{array}$ & $\begin{array}{c}0.48 \\
(0.00)\end{array}$ & $\begin{array}{c}0.23 \\
(0.00)\end{array}$ & $\begin{array}{c}0.20 \\
(0.00)\end{array}$ & 1.00 & & & & & & \\
\hline (6) & schooling & $\begin{array}{l}-0.43 \\
(0.00)\end{array}$ & $\begin{array}{c}0.40 \\
(0.00)\end{array}$ & $\begin{array}{c}0.11 \\
(0.00)\end{array}$ & $\begin{array}{c}0.10 \\
(0.00)\end{array}$ & $\begin{array}{c}0.42 \\
(0.00)\end{array}$ & 1.00 & & & & & \\
\hline (7) & trade openness & $\begin{array}{l}-0.22 \\
(0.00)\end{array}$ & $\begin{array}{c}0.27 \\
(0.00)\end{array}$ & $\begin{array}{c}0.29 \\
(0.00)\end{array}$ & $\begin{array}{c}0.28 \\
(0.00)\end{array}$ & $\begin{array}{c}0.26 \\
(0.00)\end{array}$ & $\begin{array}{c}0.27 \\
(0.00)\end{array}$ & 1.00 & & & & \\
\hline (8) & $\begin{array}{l}\text { population } \\
\text { growth }\end{array}$ & $\begin{array}{c}0.43 \\
(0.00)\end{array}$ & $\begin{array}{r}-0.05 \\
(0.06)\end{array}$ & $\begin{array}{r}-0.01 \\
(0.73)\end{array}$ & $\begin{array}{r}-0.03 \\
(0.27)\end{array}$ & $\begin{array}{r}-0.30 \\
(0.00)\end{array}$ & $\begin{array}{r}-0.44 \\
(0.00)\end{array}$ & $\begin{array}{r}-0.06 \\
(0.02)\end{array}$ & 1.00 & & & \\
\hline (9) & $\begin{array}{l}\text { per capita GDP } \\
\text { growth }\end{array}$ & $\begin{array}{r}-0.05 \\
(0.18)\end{array}$ & $\begin{array}{c}0.02 \\
(0.41)\end{array}$ & $\begin{array}{r}-0.04 \\
(0.23)\end{array}$ & $\begin{array}{l}-0.03 \\
(0.27)\end{array}$ & $\begin{array}{l}-0.04 \\
(0.22)\end{array}$ & $\begin{array}{c}0.03 \\
(0.35)\end{array}$ & $\begin{array}{c}0.07 \\
(0.02)\end{array}$ & $\begin{array}{r}-0.10 \\
(0.00)\end{array}$ & 1.00 & & \\
\hline (10) & inflation & $\begin{array}{l}-0.01 \\
(0.83)\end{array}$ & $\begin{array}{l}-0.04 \\
(0.12)\end{array}$ & $\begin{array}{c}0.01 \\
(0.65)\end{array}$ & $\begin{array}{c}0.01 \\
(0.83)\end{array}$ & $\begin{array}{l}-0.06 \\
(0.08)\end{array}$ & $\begin{array}{l}-0.01 \\
(0.78)\end{array}$ & $\begin{array}{l}-0.00 \\
(0.99)\end{array}$ & $\begin{array}{l}-0.00 \\
(0.98)\end{array}$ & $\begin{array}{l}-0.20 \\
(0.00)\end{array}$ & 1.00 & \\
\hline (11) & $\begin{array}{l}\text { age dependency } \\
\text { ratio }\end{array}$ & $\begin{array}{c}0.56 \\
(0.00)\end{array}$ & $\begin{array}{l}-0.42 \\
(0.00)\end{array}$ & $\begin{array}{l}-0.14 \\
(0.00)\end{array}$ & $\begin{array}{l}-0.11 \\
(0.00)\end{array}$ & $\begin{array}{l}-0.58 \\
(0.00)\end{array}$ & $\begin{array}{l}-0.69 \\
(0.00)\end{array}$ & $\begin{array}{r}-0.25 \\
(0.00)\end{array}$ & $\begin{array}{c}0.41 \\
(0.00)\end{array}$ & $\begin{array}{l}-0.06 \\
(0.02)\end{array}$ & $\begin{array}{c}0.01 \\
(0.80)\end{array}$ & 1.00 \\
\hline
\end{tabular}

Fig. 4 presents the development of income inequality following an increase in our measure of capital account liberalization (y-axis). We use the above described Gini coefficient to measure income inequality. The $\mathrm{x}$-axis shows the time periods around increases in capital account liberalization. In the picture, capital account liberalization is equivalent to a positive change in the index measure of Chinn and Ito (2008). All shifts in the measure are lined up to date zero. In other words, period zero captures all positive shifts. This allows visualizing average income inequality following capital account liberalization. We then compute the average over all countries that experienced a positive shift. Note that we use a five-year panel, implying that the time periods are based on five-year intervals. For 


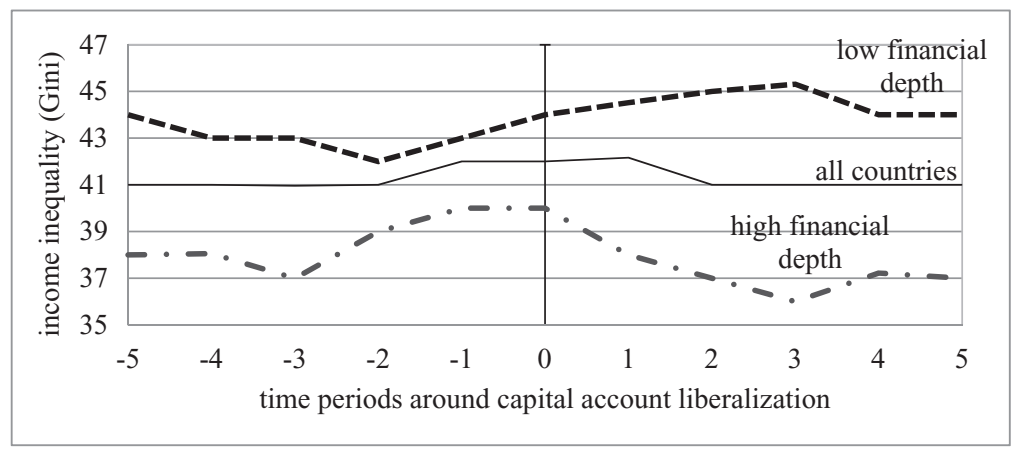

Fig. 4. Income Inequality around Capital Account Liberalization.

Notes: This figure presents the development of income inequality around an increase in the KAOPEN index of capital account liberalization due to Chinn and Ito (2008). The underlying data is a five-year panel where one observation every five years from 1973 to 2008 has been used. The cut-off value for high financial depth is the 75th percentile of private credit (in log) data. The same pattern prevails, if the cut-off is at the 50th percentile.

Table 3

Empirical results for the baseline model.

\begin{tabular}{llll}
\hline Dependent variable: inequality & \multicolumn{3}{l}{ Capital account liberalization } \\
\cline { 2 - 4 } & $(1)$ & $(2)$ & $(3)$ \\
\hline L. inequality & $0.66^{* * *}$ & $0.70^{* * *}$ & $0.70^{* * *}$ \\
flib & $(0.15)$ & $(0.13)$ & $(0.08)$ \\
& $2.26^{*}$ & $2.00^{* *}$ & $1.63^{* *}$ \\
flib x L.findepth & $(1.17)$ & $(0.91)$ & $(0.73)$ \\
& $-0.78^{* *}$ & $-0.69^{* * *}$ & $-0.51^{* *}$ \\
L.findepth & $(0.35)$ & $(0.27)$ & $(0.22)$ \\
& -0.09 & -0.70 & $-0.92^{*}$ \\
Per capita GDP growth & $(0.69)$ & $(0.53)$ & $(0.52)$ \\
& & $-0.18^{* * *}$ & $-0.14^{* *}$ \\
Constant & & $(0.09)$ & $(0.07)$ \\
Control variables & $15.62^{* *}$ & & $(0.04)$ \\
Year effects & $(7.94)$ & $16.55^{* * *}$ & $19.79^{* * *}$ \\
Observations & No & $(6.13)$ & $(5.11)$ \\
Groups & Yes & No & Yes \\
Instruments & 438 & Yes & Yes \\
Hansen-p value & 106 & 438 & 436 \\
AR2-p value & 31 & 106 & 106 \\
\hline
\end{tabular}

Notes: The underlying data is a five-year panel where one observation every five years has been used. The sample covers 106 countries observed between 1973 and 2008. The dependent variable is income inequality measured by the Gini coefficient on the basis of estimated household income inequality. A higher Gini coefficient means more income inequality. The Gini coefficient is measured on a scale of 0 to 100 to enhance the readability of the coefficients. Capital account liberalization is measured by the KAOPEN index (Chinn and Ito, 2008). Financial depth is the natural logarithm of private credit over GDP. The set of additional control variables consists of the natural logarithm of inflation, trade openness, schooling and the age dependency ratio. For all explanatory variables (except the year effects) lags two to six are used as GMM-style instruments. Moreover, the collapse option of xtabond2 has been chosen. Windmeijer-corrected standard errors are reported in parentheses. Stars ${ }^{* * *},{ }^{* *}$ and * indicate significance at the $1 \%-, 5 \%$, and the $10 \%$-level, respectively. 
Table 4

Robustness check: Capital account liberalization via financial depth.

\begin{tabular}{llll}
\hline Dependent variable: inequality & \multicolumn{3}{l}{ Capital account liberalization } \\
\cline { 2 - 3 } & $(1)$ & $(2)$ & $(3)$ \\
\hline L.inequality & $0.65^{* * *}$ & $0.66^{* * *}$ & $0.66^{* * *}$ \\
flib & $(0.13)$ & $(0.13)$ & $(0.09)$ \\
& $2.32^{* *}$ & $2.20^{* *}$ & $1.90^{* *}$ \\
flib x L.findepth & $(1.18)$ & $(0.99)$ & $(0.82)$ \\
& $-0.83^{* *}$ & $-0.79^{* * *}$ & $-0.60^{* *}$ \\
L.findepth & $(0.33)$ & $(0.28)$ & $(0.24)$ \\
& 0.36 & -0.35 & -0.26 \\
findepth & $(0.75)$ & $(0.68)$ & $(0.55)$ \\
Per capita GDP growth & -0.53 & -0.22 & -0.44 \\
& $(0.96)$ & $(0.93)$ & $(0.88)$ \\
Constant & & -0.14 & $-0.15^{*}$ \\
Control variables & & $(0.09)$ & $(0.08)$ \\
Year effects & $16.53^{* *}$ & $17.83^{* *}$ & $20.83^{* * *}$ \\
Observations & $(7.93)$ & $(8.01)$ & $(7.02)$ \\
Groups & No & No & Yes \\
Instruments & Yes & Yes & Yes \\
Hansen p-value & 438 & 438 & 436 \\
AR2 p-value & 106 & 106 & 106 \\
\hline
\end{tabular}

Notes: The underlying data is a five-year panel where one observation every five years has been used. The sample covers 106 countries observed between 1973 and 2008. The dependent variable is income inequality measured by the Gini coefficient on the basis of estimated household income inequality. A higher Gini coefficient means more income inequality. The Gini coefficient is measured on a scale of 0 to 100 to enhance the readability of the coefficients. Capital account liberalization is measured by the KAOPEN index (Chinn and Ito, 2008). Financial depth is the natural logarithm of private credit over GDP. The set of additional control variables consists of the natural logarithm of inflation, trade openness, schooling and the age dependency ratio. For all explanatory variables (except the year effects), lags two to six are used as GMM-style instruments. Moreover, the collapse option of xtabond2 has been chosen. Windmeijer-corrected standard errors are reported in parentheses. Stars ${ }^{* * *},{ }^{* *}$ and * indicate significance at the $1 \%-, 5 \%$-, and the $10 \%$-level, respectively.

example, period one refers to the first five years after a positive shift and period two to the second five-year interval.

The solid line includes all countries in the dataset. It does not display a clear trend change in the wake of capital account liberalization. The bottom line only includes countries with a high level of financial depth (proxied by private credit over GDP), where high means the 75th percentile of the sample distribution. The top line summarizes the evolution of income inequality in countries with financial depth smaller than the 75th percentile. Interestingly, the Gini coefficient declines after capital account liberalization in countries with large financial depth, while it continues to go up in countries with a lower level of financial depth. The figure, thus, hints at the moderating role of financial depth. Moreover, we note that, on average, capital account liberalization is preceded by a rise in the Gini coefficient. A proper econometric model should take these dynamics into account by including lagged income inequality an as an independent variable.

\section{Empirical results}

Table 3 contains the first set of results showing estimates of equation 17. Column one presents a parsimonious model that only includes the interaction term and its constitutive components, 
Table 5

Robustness check: Excluding very large observations.

\begin{tabular}{llll}
\hline Dependent variable: inequality & \multicolumn{3}{l}{ Capital account liberalization } \\
\cline { 2 - 3 } & $(1)$ & $(2)$ & $(3)$ \\
\hline L.inequality & $0.65^{* * *}$ & $0.71^{* * *}$ & $0.64^{* * *}$ \\
flib & $(0.14)$ & $(0.12)$ & $(0.08)$ \\
& 1.90 & $2.44^{* * *}$ & $1.86^{* *}$ \\
flib x L.findepth & $(1.32)$ & $(0.90)$ & $(0.87)$ \\
& $-0.70^{*}$ & $-0.79^{* * *}$ & $-0.59^{* *}$ \\
L.findepth & $(0.37)$ & $(0.25)$ & $(0.25)$ \\
& -0.30 & -0.67 & $-0.91^{* *}$ \\
Per capita GDP growth & $(0.62)$ & $(0.49)$ & $(0.46)$ \\
& & $-0.26^{* * *}$ & $-0.14^{* *}$ \\
Constant & & $(0.09)$ & $(0.07)$ \\
& $16.89^{* *}$ & $15.96^{* * *}$ & $21.08^{* * *}$ \\
Control variables & $(7.29)$ & $(5.68)$ & $(5.05)$ \\
Year effects & No & No & Yes \\
Observations & Yes & Yes & Yes \\
Groups & 425 & 425 & 423 \\
Instruments & 105 & 105 & 105 \\
Hansen p-value & 31 & 37 & 67 \\
AR2 p-value & 0.17 & 0.78 & 0.58 \\
\hline
\end{tabular}

Notes: The sample excludes observations of the inequality measure that exceed its average value by more than 1.5 standard deviations. The underlying data is a five-year panel where one observation every five years has been used. The sample covers the period 1973 to 2008 . The dependent variable is income inequality measured by the Gini coefficient on the basis of estimated household income inequality. A higher Gini coefficient means more income inequality. The Gini coefficient is measured on a scale of 0 to 100 to enhance the readability of the coefficients. Capital account liberalization is measured by the KAOPEN index (Chinn and Ito, 2008). Financial depth is the natural logarithm of private credit over GDP. The set of additional control variables consists of the natural logarithm of inflation, trade openness, schooling and the age dependency ratio. For all explanatory variables (except the year effects) lags two to six are used as GMM-style instruments. Moreover, the collapse option of xtabond2 has been chosen. Windmeijercorrected standard errors are reported in parentheses. Stars ***, ** and * indicate significance at the $1 \%-, 5 \%-$, and the $10 \%$-level, respectively.

without further control variables. ${ }^{5}$ The point estimates of our coefficients of interest are 2.26 and -0.78 , respectively. ${ }^{6}$ The significantly positive sign on $\lambda$ suggests that capital account liberalization tends to increase income inequality. But the relationship between capital account liberalization and income inequality varies by level of financial depth, as indicated by the significant coefficient on the interaction term. More precisely, the negative sign on $\delta$ implies that the greater financial depth, the smaller (less detrimental) the effect of capital account liberalization on income inequality may be.

In columns two and three, we include per capita GDP growth and further control variables. The coefficients on capital account liberalization and the interaction term decrease in magnitude but remain significant. In all regressions, the Hansen test statistic indicates the validity of the overidentifying restrictions. Moreover, there is no evidence for second-order autocorrelation (AR2).

An interesting question to ask is above which level of financial depth, capital account liberalization reduces income inequality. The results in column three imply that this cutoff point is at a private credit-to-GDP ratio greater than 25 percent. In our sample, there are 161 observations with a private credit ratio below and 275 observations above this threshold. Obviously, most of the observations with a private credit ratio below 25 percent come from low income and lower middle income countries. Thus, in these countries, capital account liberalization is more likely to increase income inequality.

\footnotetext{
5 The Gini coefficient is measured on a scale of 0 to 100 to enhance the readability of the coefficients.

6 The predicted values of the Gini coefficient fall inside the desired range between 0 and 100 .
} 
Table 6

Robustness check: Excluding very small observations.

\begin{tabular}{llll}
\hline Dependent variable: inequality & \multicolumn{2}{l}{} \\
\hline & \multicolumn{2}{l}{ Capital account liberalization } & $(3)$ \\
\cline { 2 - 4 } & $(1)$ & $(2)$ & $0.74^{* * *}$ \\
\hline L. inequality & $0.94^{* * *}$ & $0.87^{* * *}$ & $(0.12)$ \\
flib & $(0.14)$ & $(0.13)$ & $1.30^{*}$ \\
& 1.25 & $2.30^{* *}$ & $(0.72)$ \\
flib x L.findepth & $(1.65)$ & $(1.05)$ & $-0.42^{*}$ \\
& -0.36 & $-0.63^{* *}$ & $(0.22)$ \\
L.findepth & $(0.46)$ & $(0.29)$ & -0.83 \\
& -0.59 & -0.57 & $(0.53)$ \\
Per capita GDP growth & $(0.64)$ & $(0.41)$ & $-0.22^{* *}$ \\
Constant & & $-0.20^{* *}$ & $(0.09)$ \\
& & $(0.10)$ & $13.84^{*}$ \\
Control variables & 4.40 & 7.74 & $(7.13)$ \\
Year effects & $(6.19)$ & $(5.89)$ & Yes \\
Observations & No & No & Yes \\
Groups & Yes & Yes & 411 \\
Instruments & 413 & 413 & 104 \\
Hansen p-value & 104 & 104 & 67 \\
AR2 p-value & 31 & 37 & 0.75 \\
\hline
\end{tabular}

Notes: This table excludes observations of the inequality measure that are more than 1.5 standard deviations below the average. The underlying data is a five-year panel where one observation every five years has been used. The sample covers the time period 1973 to 2008 . The dependent variable is income inequality measured by the Gini coefficient on the basis of estimated household income inequality. A higher Gini coefficient means more income inequality. The Gini coefficient is measured on a scale of 0 to 100 to enhance the readability of the coefficients. Capital account liberalization is measured by the KAOPEN index (Chinn and Ito, 2008). Financial depth is the natural logarithm of private credit over GDP. The set of additional control variables consists of the natural logarithm of inflation, trade openness, schooling and the age dependency ratio. For all explanatory variables (except the year effects), lags two to six are used as GMM-style instruments. Moreover, the collapse option of xtabond2 has been chosen. Windmeijercorrected standard errors are reported in parentheses. Stars ***, ** and * indicate significance at the 1\%-, 5\%-, and the $10 \%$-level, respectively.

\section{Robustness analyses}

The specification in equation 17 assumes that financial depth stays constant following capital account liberalization. However, it may be the case that capital account liberalization induces changes in financial depth. ${ }^{7}$ If this would be the case, the impact of capital account liberalization on income inequality would (partly) be channeled through financial depth. In order to test this potential channel, we reformulate the model by including the current level of financial depth:

$$
\begin{aligned}
\text { inequality }_{i, t}= & \text { constant } \text { pinequality }_{i, t-1}+\lambda \text { flib }_{i, t}+\theta \text { findepth }_{i, t}+\beta \text { findepth }_{i, t-1} \\
& +\delta\left(\text { flib }_{i, t} \times \text { findepth }_{i, t-1}\right)+x_{i t}^{\prime} \gamma+\eta_{i}+\mu_{t}+\varepsilon_{i, t} .
\end{aligned}
$$

\footnotetext{
7 Appendix S4 presents an alternative model showing the impact of a financial liberalization on income distribution if financial depth is positively affected by capital account liberalization.

8 The impact of financial liberalization on financial depth is ambiguous, though. For instance the financial restraint literature, emphasizing the role of information asymmetries, points out that banking sector liberalizations and the related increase in competition among banks could actually aggravate the problem of information incompleteness. For example, declining interest rate margins could encourage banks to economize on screening and monitoring efforts. Similarly, banks might be inclined to accept levels of risk exposure beyond usual standards in order to increase profits, or opt for gambling strategies in their loan allocation decisions (Boot, 2000; Hellmann et al., 2000; Stulz, 1999). The so-called Neo Structuralists even argue that financial liberalization may lead to a reallocation of funds from the informal sector to the formal sector, such that the total supply of funds available for investment (financial depth) does not increase or even declines. (e.g., van Wijnbergen 1982; Taylor 1983).
} 
If financial depth correlates positively with capital account liberalization, and negatively with income inequality, we would expect that the coefficient on capital account liberalization $\lambda$ in equation 18 is greater in magnitude compared with its value in the base model (equation 17). The reason is that part of the impact of a capital account liberalization on income inequality will be picked up by $\theta$.

Table 4 reports results for equation 18. Compared with Table 3, the coefficients on capital account liberalization have increased in terms of magnitude. However, conducting a t-test, we find that the differences between the coefficients are not statistically significant. Thus, the effect of capital account liberalization on income inequality is similar in both specifications. This suggests that the impact of a capital account liberalization on income inequality is not channeled through financial depth, and that our base model is correctly specified.

We also assess to what extent our results depend on very large and small observations of our income inequality measure, respectively. Therefore, we exclude observations with a value of the Gini coefficient more than 1.5 standard deviations below or above the average. We begin by excluding observations of the Gini coefficient that exceed its average value by more than 1.5 standard deviations.

Table 5 shows slight changes in the point estimates of both capital account liberalization and the interaction term. These changes are statistically insignificant though. Next, Table 6 presents results if we omit observations with very small Gini coefficients from the dataset. It appears that our coefficients of interest are affected. Yet, for the full model in column three, the coefficients of interest are still significant, albeit only at the ten percent level.

Second, we exclude Sub-Saharan countries from the sample because their data is more likely to be of poor quality since the accuracy of income inequality data potentially rises with the level of economic development. Table 7 gives the results.

Table 7

Robustness check: Excluding Sub-Saharan countries.

\begin{tabular}{lccc}
\hline Dependent variable: inequality & \multicolumn{3}{c}{ Capital account liberalization } \\
\cline { 2 - 4 } & $(1)$ & $(2)$ & $(3)$ \\
\hline L.inequality & $0.58^{* * *}$ & $0.58^{* * *}$ & $0.73^{* * *}$ \\
flib & $(0.16)$ & $(0.15)$ & $(0.08)$ \\
& 2.05 & $2.30^{* *}$ & $1.58^{*}$ \\
flib x L.findepth & $(1.31)$ & $(1.07)$ & $(0.92)$ \\
& $-0.68^{*}$ & $-0.79^{* *}$ & $-0.50^{* *}$ \\
L.findepth & $(0.40)$ & $(0.31)$ & $(0.25)$ \\
& -0.55 & -0.50 & -0.68 \\
Per capita GDP growth & $(0.65)$ & $(0.61)$ & $(0.63)$ \\
Constant & & -0.04 & $-0.18^{*}$ \\
Control variables & & $(0.15)$ & $(0.10)$ \\
Year effects & $20.19^{* * *}$ & $20.66^{* * *}$ & $19.06^{* * *}$ \\
Observations & $(7.41)$ & $(6.89)$ & $(5.60)$ \\
Groups & No & No & Yes \\
Instruments & Yes & Yes & Yes \\
Hansen p-value & 369 & 369 & 367 \\
AR2 p-value & 85 & 85 & 85 \\
\hline
\end{tabular}

Notes: This sample excludes observations from Sub-Saharan countries from the sample. The underlying data is a five-year panel where one observation every five years has been used. The sample covers the time period 1973 to 2008. The dependent variable is income inequality measured by the Gini coefficient on the basis of estimated household income inequality. A higher Gini coefficient means more income inequality. The Gini coefficient is measured on a scale of 0 to 100 to enhance the readability of the coefficients. Capital account liberalization is measured by the KAOPEN index (Chinn and Ito, 2008). Financial depth is the natural logarithm of private credit over GDP. The set of additional control variables consists of the natural logarithm of inflation, trade openness, schooling and the age dependency ratio. For all explanatory variables (except the year effects) lags two to six are used as GMM-style instruments. Moreover, the collapse option of xtabond 2 has been chosen. Windmeijer-corrected standard errors are reported in parentheses. Stars ***, ** and * indicate significance at the $1 \%-, 5 \%-$, and the $10 \%$-level, respectively. 
Table 8

Robustness check: De facto capital account liberalization.

\begin{tabular}{lccc}
\hline Dependent variable: inequality & \multicolumn{3}{c}{ De facto capital account liberalization } \\
\cline { 2 - 4 } & $(1)$ & $(2)$ & $(3)$ \\
\hline L.inequality & $0.71^{* * *}$ & $0.64^{* * *}$ & $0.63^{* * *}$ \\
& $(0.12)$ & $(0.16)$ & $(0.12)$ \\
De facto flib & -1.81 & -2.98 & -0.58 \\
& $(2.67)$ & $(2.85)$ & $(2.17)$ \\
De facto flib x L. fin.depth & 0.21 & 0.24 & -0.22 \\
& $(0.69)$ & $(0.65)$ & $(0.53)$ \\
L.fin.depth & -0.80 & $-1.03^{*}$ & -0.80 \\
& $(0.73)$ & $(0.60)$ & $(0.60)$ \\
Per capita GDP growth & & $-0.18^{*}$ & $-0.20^{* * *}$ \\
Constant & $14.87^{* *}$ & $(0.10)$ & $(0.07)$ \\
& $(6.80)$ & $20.07^{* *}$ & $21.56^{* * *}$ \\
Control variables & No & $(7.84)$ & $(5.78)$ \\
Year effects & Yes & No & Yes \\
Observations & 429 & 429 & Yes \\
Groups & 106 & 106 & 427 \\
Instruments & 31 & 37 & 106 \\
Hansen-p value & 0.27 & 0.32 & 67 \\
AR2-p value & 0.74 & 0.68 & 0.71 \\
\hline
\end{tabular}

Notes: This table uses the natural logarithm of the sum of equity assets, equity liabilities, fdi assets, fdi liabilities, debt assets, debt liabilities, derivatives assets, derivatives liabilities and foreign exchange over GDP as a de facto measure of capital account liberalization. The underlying data is a five-year panel where one observation every five years has been used. The sample covers 106 countries observed between 1973 and 2008. The dependent variable is income inequality measured by the Gini coefficient on the basis of estimated household income inequality. A higher Gini coefficient means more income inequality. The Gini coefficient is measured on a scale of 0 to 100 to enhance the readability of the coefficients. Financial depth is the natural logarithm of private credit over GDP. The set of additional control variables consists of the natural logarithm of inflation, trade openness, schooling and the age dependency ratio. For all explanatory variables (except the year effects) lags two to six are used as GMM-style instruments. Moreover, the collapse option of xtabond2 has been chosen. Windmeijer-corrected standard errors are reported in parentheses. Stars ***, ** and * indicate significance at the $1 \%-, 5 \%-$, and the $10 \%$-level, respectively.

The table shows that the main results are not affected, if Sub-Saharan African countries are excluded.

In our baseline regressions (see Table 3), we are using the KAOPEN index of capital account liberalization, which can be categorized as a so-called de jure measure of capital account liberalization because it captures the existence of legal restrictions on international capital transactions. Apart from this type of measure, there also exist de facto measures referring to actual capital stocks and flows. In the literature, there is a debate about the advantages and disadvantages of de facto and de jure measures (Kose et al., 2006, 2010). In view of this debate, we are using foreign direct investment over GDP (the main proxy for financial globalization used by Jaumotte et al., 2013) and a de facto measure of capital account openness due to Lane and Milesi-Ferretti (2007) to assess the relationship between de facto capital account liberalization and income inequality in further robustness checks. ${ }^{9}$

The results in Table 8 show that the coefficients of interest, the de facto measure of capital account liberalization and its interaction with financial depth are statistically insignificant. The insignificance could result from the fact that actual capital flows are influenced by many different factors unrelated to capital account liberalization.

Table 9 displays the results for foreign direct investment. By and large, the results support our main conclusion. When we include per capita GDP growth and further control variables (column 3), we obtain a statistically significant negative coefficient on the interaction term and a statistically positive coefficient on fdi. The latter result partly confirms Jaumotte et al. (2013): financial globalization is associated

\footnotetext{
${ }^{9}$ De facto capital account liberalization $=($ equity assets + equity liabilities + fdi assets + fdi liabilities + debt assets + debt liabilities + derivatives assets + derivatives liabilities $+\mathrm{fx}$ )/GDP. This measure is considered as the most useful de facto measure of a country's exposure to international finance (Quinn and Toyoda, 2008).
} 
Table 9

Robustness check: Foreign direct investment.

\begin{tabular}{|c|c|c|c|}
\hline \multicolumn{4}{|c|}{ Dependent variable: inequality } \\
\hline & \multicolumn{3}{|c|}{ Foreign direct investment } \\
\hline & (1) & $(2)$ & (3) \\
\hline \multirow[t]{2}{*}{ L. inequality } & $0.73^{* * *}$ & $0.74^{* * *}$ & $0.70^{* * *}$ \\
\hline & $(0.12)$ & $(0.10)$ & $(0.08)$ \\
\hline \multirow[t]{2}{*}{ fdi } & 1.44 & 1.64 & $2.33^{* *}$ \\
\hline & $(1.00)$ & $(1.05)$ & $(1.18)$ \\
\hline \multirow[t]{2}{*}{ fdi x L.fin.depth } & -0.28 & $-0.53^{*}$ & $-0.67^{* *}$ \\
\hline & $(0.23)$ & $(0.28)$ & $(0.30)$ \\
\hline \multirow[t]{2}{*}{ L.fin.depth } & $-1.59^{* *}$ & $-2.09^{* * *}$ & $-2.27^{* * *}$ \\
\hline & $(0.62)$ & $(0.71)$ & $(0.54)$ \\
\hline \multirow[t]{2}{*}{ Per capita GDP growth } & & $-0.30^{* * *}$ & $-0.23^{* * *}$ \\
\hline & & $(0.11)$ & $(0.08)$ \\
\hline \multirow[t]{2}{*}{ Constant } & $17.26^{* * *}$ & $18.82^{* * *}$ & $23.70^{* * *}$ \\
\hline & $(5.65)$ & $(5.19)$ & $(5.53)$ \\
\hline Control variables & No & No & Yes \\
\hline Year effects & Yes & Yes & Yes \\
\hline Observations & 432 & 432 & 430 \\
\hline Groups & 106 & 106 & 106 \\
\hline Instruments & 31 & 37 & 67 \\
\hline Hansen-p value & 0.33 & 0.78 & 0.50 \\
\hline AR2-p value & 0.97 & 0.97 & 0.87 \\
\hline
\end{tabular}

Notes: This table uses the natural logarithm of foreign direct investment over GDP as a de facto measure of capital account liberalization. The underlying data is a five-year panel where one observation every five years has been used. The sample covers 106 countries observed between 1973 and 2008. The dependent variable is income inequality measured by the Gini coefficient on the basis of estimated household income inequality. A higher Gini coefficient means more income inequality. The Gini coefficient is measured on a scale of 0 to 100 to enhance the readability of the coefficients. Financial depth is the natural logarithm of private credit over GDP. The set of additional control variables consists of the natural logarithm of inflation, trade openness, schooling and the age dependency ratio. For all explanatory variables (except the year effects) lags two to six are used as GMM-style instruments. Moreover, the collapse option of xtabond2 has been chosen. Windmeijer-corrected standard errors are reported in parentheses. Stars ${ }^{* * *},{ }^{* *}$ and ${ }^{*}$ indicate significance at the $1 \%-, 5 \%-$, and the $10 \%$-level, respectively.

with an increase in inequality. However, our analyses suggest that this probably only holds for countries with a low level of financial depth, i.e. the low and lower-middle income countries.

A final robustness check is induced by a recent paper by Sturm and De Haan (2015). Their analyses suggest that capitalist countries with a low degree of fractionalization are characterized by substantial redistribution, whereas highly fractionalized countries redistribute significantly less. The underlying idea is that more homogenous societies in terms of language, ethnicity and religion tend to be less unequal due to a higher willingness to redistribute income. Therefore, it is interesting to see to what extent our main results as presented in Table 3 still hold if we include measures of ethnic and linguistic fractionalization. The required data have been taken from Sturm and De Haan (2015). Table 10 shows the results for the various fractionalization measures used in Sturm and De Haan (2015). It appears that only one fractionalization measure is significant. Most importantly, the coefficients of our baseline model (shown in column 1 ) are only marginally affected.

\section{Conclusion}

This paper investigates the impact of a capital account liberalization on income inequality. The theoretical analyses as well as the empirical estimates suggest that the effect of a capital account liberalization on income inequality depends on the level of financial depth. This finding persists if we include control variables, exclude outliers and omit Sub-Saharan countries from the sample. While further robustness checks inevitably generate varying point estimates, the overall result is, nonetheless, a consistent picture. According to the estimates, a capital account liberalization only tends to lower income inequality if the level of financial depth, as measured by private credit over GDP, exceeds 25 
Table 10

Robustness check: Ethnic, religious and linguistic fractionalization.

\begin{tabular}{|c|c|c|c|c|c|c|c|}
\hline \multicolumn{8}{|c|}{ Dependent variable: inequality } \\
\hline & \multicolumn{7}{|c|}{ Capital account liberalization } \\
\hline & (1) & $(2)$ & (3) & $(4)$ & (5) & (6) & (7) \\
\hline L. inequality & $\begin{array}{l}0.70^{* * *} \\
(0.08)\end{array}$ & $\begin{array}{l}0.66^{* * *} \\
(0.10)\end{array}$ & $\begin{array}{l}0.71^{* * * *} \\
(0.08)\end{array}$ & $\begin{array}{l}0.71^{* * *} \\
(0.08)\end{array}$ & $\begin{array}{l}0.68^{* * *} \\
(0.10)\end{array}$ & $\begin{array}{l}0.68^{* * *} \\
(0.10)\end{array}$ & $\begin{array}{l}0.67^{* * *} \\
(0.11)\end{array}$ \\
\hline Flib & $\begin{array}{l}1.63^{* *} \\
(0.73)\end{array}$ & $\begin{array}{l}1.63^{* *} \\
(0.75)\end{array}$ & $\begin{array}{l}1.62^{* *} \\
(0.71)\end{array}$ & $\begin{array}{l}1.93^{* *} \\
(0.77)\end{array}$ & $\begin{array}{c}1.68^{* *} \\
(0.79)\end{array}$ & $\begin{array}{l}1.64^{* *} \\
(0.68)\end{array}$ & $\begin{array}{l}1.58^{* *} \\
(0.79)\end{array}$ \\
\hline flib x L.fin.depth & $\begin{array}{l}-0.51^{* *} \\
(0.22)\end{array}$ & $\begin{array}{l}-0.49^{* *} \\
(0.22)\end{array}$ & $\begin{array}{l}-0.49^{* *} \\
(0.21)\end{array}$ & $\begin{array}{l}-0.60^{* * * *} \\
(0.23)\end{array}$ & $\begin{array}{l}-0.53^{* *} \\
(0.22)\end{array}$ & $\begin{array}{l}-0.51^{* * *} \\
(0.19)\end{array}$ & $\begin{array}{l}-0.50^{* *} \\
(0.22)\end{array}$ \\
\hline L.fin.depth & $\begin{array}{l}-0.92^{*} \\
(0.52)\end{array}$ & $\begin{array}{l}-1.01^{* *} \\
(0.50)\end{array}$ & $\begin{array}{l}-1.16^{* *} \\
(0.51)\end{array}$ & $\begin{array}{l}-0.97^{*} \\
(0.51)\end{array}$ & $\begin{array}{l}-1.00^{* *} \\
(0.50)\end{array}$ & $\begin{array}{l}-1.01^{* *} \\
(0.47)\end{array}$ & $\begin{array}{l}-1.01^{* *} \\
(0.50)\end{array}$ \\
\hline fract. Ethnic & & $\begin{array}{l}3.35 \\
(2.54)\end{array}$ & & & & & \\
\hline fract. Language & & & $\begin{array}{c}1.58 \\
(1.41)\end{array}$ & & & & \\
\hline fract. Religion & & & & $\begin{array}{c}1.75 \\
(1.28)\end{array}$ & & & \\
\hline fract. ethno-linguistic ELF1 & & & & & $\begin{array}{c}1.74 \\
(1.77)\end{array}$ & & \\
\hline fract. ethno-linguistic ELF & & & & & & $\begin{array}{r}2.58^{*} \\
(1.34)\end{array}$ & \\
\hline $\begin{array}{l}\text { fract. ethno-linguistic } \\
\text { ELF-distances }\end{array}$ & & & & & & & 2.71 \\
\hline Constant & $\begin{array}{l}19.79^{* * *} \\
(5.11)\end{array}$ & $\begin{array}{l}21.20^{* * *} \\
(4.83)\end{array}$ & $\begin{array}{l}20.29^{* * *} \\
(4.55)\end{array}$ & $\begin{array}{l}19.14^{* * *} \\
(4.96)\end{array}$ & $\begin{array}{l}21.31^{* * *} \\
(5.43)\end{array}$ & $\begin{array}{l}20.91^{* * *} \\
(5.15)\end{array}$ & $\begin{array}{l}(1.97) \\
21.22^{* * *} \\
(5.52)\end{array}$ \\
\hline Control variables & Yes & Yes & Yes & Yes & Yes & Yes & Yes \\
\hline Year effects & Yes & Yes & Yes & Yes & Yes & Yes & Yes \\
\hline Observations & 436 & 435 & 430 & 435 & 431 & 425 & 425 \\
\hline Groups & 106 & 105 & 103 & 105 & 104 & 103 & 103 \\
\hline Instruments & 67 & 68 & 68 & 68 & 68 & 68 & 68 \\
\hline Hansen-p value & 0.60 & 0.62 & 0.69 & 0.62 & 0.66 & 0.69 & 0.66 \\
\hline AR2-p value & 0.60 & 0.60 & 0.58 & 0.58 & 0.52 & 0.50 & 0.50 \\
\hline
\end{tabular}

Notes: This table assesses the robustness of the model in column 3 of Table 3 to the inclusion of different fractionalization (fract.) measures. The data for fractionalization have been taken from Sturm and De Haan (2015). The first three measures consider either ethnic, linguistic or religious fractionalization, while the last three measures are index measures of ethno-linguistic fractionalization. The difference between ELF and ELF-distances is that the latter takes distances between different ethnolinguistic groups into account. Fractionalization does not vary over time. The underlying data is a five-year panel where one observation every five years has been used. The sample covers 106 countries observed between 1973 and 2008. The dependent variable is income inequality measured by the Gini coefficient on the basis of estimated household income inequality. A higher Gini coefficient means more income inequality. The Gini coefficient is measured on a scale of 0 to 100 to enhance the readability of the coefficients. Financial depth is the natural logarithm of private credit over GDP. The set of additional control variables consists of per capita GDP growth, the natural logarithm of inflation, trade openness, schooling and the age dependency ratio. For all explanatory variables (except the year effects and fractionalization) lags two to six are used as GMM-style instruments. Fractionalization is specified as an IV instrument as it is not varying over time. Moreover, the collapse option of xtabond 2 has been chosen. Windmeijer-corrected standard errors are reported in parentheses. Stars ${ }^{* * *},{ }^{* *}$ and * indicate significance at the $1 \%-, 5 \%-$, and the $10 \%$-level, respectively.

percent. For most developing countries, where financial depth is low, this implies that a capital account liberalization will probably increase income inequality. In order to ensure that living conditions of the poor in countries with low levels of financial depth do not further worsen if a government decides to liberalize the capital account, it seems relevant to implement additional protection measures for the initially disadvantaged groups.

\section{Appendix. Supplementary material}

Supplementary data to this article can be found online at doi:10.1016/j.jimonfin.2015.10.004. 


\section{References}

Abiad, A., Detragiache, E., Tressel, T., 2010. A new database of financial reforms. IMF Staff Papers 57 (2), 281-302.

Acemoglu, D., 2002. Technical change, inequality, and the labor market. J. Econ. Lit. 40 (1), 7-72.

Acemoglu, D., Naidu, S., Restrepo, P., Robinson, J.A., 2013, “Democracy, redistribution and inequality," NBER Working Papers no. 19746, National Bureau of Economic Research.

Agénor, P.-R., Montiel, P.J., 2008. Development Macroeconomics, third ed. Princeton University Press, Princeton, NJ.

Agnello, L., Mallick, S.K., Sousa, R.M., 2012. Financial reforms and income inequality. Econ. Lett. 116 (3), 583-587.

Albanesi, S., 2007. Inflation and inequality. J. Monetary Econ. 54 (4), 1088-1114.

Anderson, E., 2005. Openness and inequality in developing countries: a review of theory and recent evidence. World Dev. 33 (7), 1045-1063.

Ang, J.B., 2010. Finance and inequality: the case of India. South. Econ. J. 76 (3), 738-761.

Atkinson, A., Bourguignon, F., 2000. Introduction: income distribution and economics. In: Atkinson, A.B., Bourguignon, F. (Eds.), Handbook of Income Distribution. Elsevier, Amsterdam, pp. 1-58.

Atkinson, A.B., Brandolini, A., 2001. Promise and pitfalls in the use of 'secondary' data-sets: income inequality in OECD countries as a case study. J. Econ. Lit. 39 (3), 771-799.

Atkinson, A.B., Morelli, S., 2011, “Economic crises and inequality”, Technical report no. HDRP-2011-06, United Nations Development Programme (UNDP).

Beck, T., Demirgüç-Kunt, A., 2008. Access to finance: an unfinished agenda. World Bank Econ. Rev. 22 (3), 383-396.

Beck, T., Demirguc-Kunt, A., Martinez Peria, M.S., 2007. Reaching out: access to and use of banking services across countries. J. Financ. Econ. 85 (1), 234-266.

Blundell, R., Bond, S., 1998. Initial conditions and moment restrictions in dynamic panel data models. J. Econom. 87 (1), 115-143. Boot, A.W.A., 2000. Relationship banking: what do we know? J. Financ. Intermed. 9 (1), 7-25.

Chinn, M.D., Ito, H., 2008. A new measure of financial openness. JCPA 10 (3), 309-322.

Cornia, G.A., Kiiski, S., 2001, "Trends in income distribution in the post-World War II period evidence and interpretation", UNU-WIDER Discussion Papers no. 2001/89, World Institute for Development Economic Research (UNU-WIDER).

Deininger, K., Squire, L., 1996. A new data set measuring income inequality. World Bank Economic Review 10 (3), $565-591$.

Delis, M.D., Hasan, I., Kazakis, P., 2014. Bank regulations and income inequality: empirical evidence. Rev. Financ. 18 (5), $1811-1846$.

Demirgüç-Kunt, A., Levine, R., 2009. Finance and inequality: theory and evidence. Annu. Rev. Financ. Economics. 1 (1), $287-318$.

Dollar, D., Kraay, A., 2002. Growth is good for the poor. J. Econ. Growth 7 (3), 195-225.

Galbraith, J.K., Kum, H., 2005. Estimating the inequality of household incomes: a statistical approach to the creation of a dense and consistent global data set. Rev. Income Wealth 51 (1), 115-143.

Galor, O., Zeira, J., 1993. Income distribution and macroeconomics. Rev. Econ. Stud. 60 (1), 35-52.

Goldin, C., Katz, L.F., 2007, Long-run changes in the U.S. wage structure: narrowing, widening, polarizing, National Bureau of Economic Research, no. 13568.

Gordon, R.J., Dew-Becker, I., 2008, “Controversies about the rise of American inequality: a survey”, NBER Working Paper Series no. 13982, National Bureau of Economic Research.

Greenwood, J., Jovanovic, B., 1990. Financial development, growth, and the distribution of income. J. Polit. Econ. 98, $1076-1107$.

Hellmann, T., Murdock, K., Stiglitz, J.E., 2000. Liberalization, moral hazard in banking and prudential regulation: are capital requirements enough? Am. Econ. Rev. 90 (1), 147-165.

Jaumotte, F., Lall, S., Papageorgiou, C., 2013. Rising income inequality: technology, or trade and financial globalization? IMF Econ. Rev. 61 (2), 271-309.

Kose, M.A., Prasad, E.S., Rogoff, K., Wei, S.-J., 2006, “Financial Globalization: A Reappraisal”, IMF Working Paper no. 06/189, International Monetary Fund.

Kose, M.A., Prasad, E.S., Rogoff, K., Wei, S.-J., 2010. Financial globalization and economic policies. In: Handbook of Development Economics, vol. 5. Elsevier, Amsterdam, pp. 4283-4359.

Krueger, A.B., 1999. Measuring labor's share. Am. Econ. Rev. 89 (2), 45-51.

Kunieda, T., Okada, K., Shibata, A., 2014. Finance and inequality: how does globalization change their relationship? Macroecon. Dyn. 18 (5), 1091-1128.

Kuznets, S., 1955. Economic growth and income inequality. Am. Econ. Rev. 45 (1), 1-28.

Lane, P.R., Milesi-Ferretti, G.M., 2007. The external wealth of nations mark II: revised and extended estimates of foreign assets and liabilities, 1970-2004. J. Int. Econ. 73 (2), 223-250.

Perotti, R., 1996. Growth, income distribution, and democracy: what the data say. J. Econ. Growth 1 (2), 149-187.

Quinn, D.P., Toyoda, A.M., 2008. Does capital account liberalization lead to growth? Rev. Financ. Stud. 21 (3), 1403-1449.

Roodman, D., 2009. How to do xtabond2: an introduction to difference and system GMM in Stata. Stata J. 9 (1), 86-136.

Stulz, R.M., 1999, "Globalization of equity markets and the cost of capital", NBER Working Paper no. 7021, National Bureau of Economic Research.

Sturm, J.-E., De Haan, J., 2015. Income inequality, capitalism, and ethno-linguistic fractionalization. Am. Econ. Rev. 105 (5), $593-597$. Taylor, L., 1983. Structuralist macroeconomics: applicable models for the third world. Basic Books, New York.

van Wijnbergen, S., 1982. Stagflationary effects of monetary stabilization policies: a quantitative analysis of South Korea. J. Dev. Econ. 18 (2), 133-169.

von Hagen, J., Zhang, H., 2008. Financial frictions, capital reallocation, and aggregate fluctuations. J. Econ. Dyn. Control 32 (3), 978-999.

Windmeijer, F., 2005. A finite sample correction for the variance of linear e-cient two-step GMM estimators. J. Econom. 126 (1), 25-51. 